\title{
Diachronic exploitation of landscape resources - tangible and intangible industrial heritage and their synthesis suspended step
}

\author{
Georgia Zacharopoulou** \\ ${ }^{1}$ GREEK MINISTRY OF CULTURE - MOUSON 89-91, 54634, THESSALONIKI, Greece
}

\begin{abstract}
It is expected that industrial heritage actually tells the story of the emerging capitalism highlighting the dynamic social relationship between the "workers" and the owners of the "production means". In current times of economic crisis, it may even involve a painful past with lost social, civil, gender and/or class struggles, a depressing present with abandoned, fragmented, degraded landscapes and ravaged factories, and a hopeless future for the former workers of the local (not only) society; or just a conquerable ground for controversial investments. This is certainly an emotionally charged subject matter, with multiple readings and interpretations.

However, this view is only partial when facing landscape during its historical evolution process. A diachronic study, thus, embraces all resources that probably gave rise to a variety of human activities; all of them embody heritage values -"subjectively" or "objectively" perceivedtheir evaluation, though, is a matter of an on-going process of the civil society.
\end{abstract}

Greece's landscape accommodates a diversity of diachronic productive practices that may overlap historical periods, technological evolutions and social transformations. Pre-, early and industrial exploitation of resources does not remain firm but vary according to time and the needs of each society. The comparative scale of certain resource exploitation is highlighted as the key for the assessment methodology in close relation to the specific frame of a local landscape and a historical period.

Even though archaeological evidence may possibly reveal and document continuity in a range of sustainable productive processes without conflicts, great controversies emerge when new investments are "offered" as an antidote to economic crisis -not harmonized to the local scale, traumatizing thus the "spirit" of the landscape. Suggestions for incompatible productive use and investment planning imply irreversible and irreparable effects on the environment, society and economy of a region and are only faced through social awareness. Case studies of passive and/or active involvement of local communities, in synthesizing and enhance landscape's "spirit", its diachronic industrial heritage and the embedded tangible and intangible values, will support a pragmatic -not a suspended- step towards a sustainable future.

Quoting Neil Cossons (TICCIH Congress 2012) "Industrial imperialism ensures its position and protects its future not by the conquest of distant lands as by the securing of its sources of raw materials ... The modern world is as much under the control of the major industrial powers as it ever was during the colonial era"; if such a case can the industrial heritage sector remain apolitical?

\footnotetext{
${ }^{*}$ Speaker
} 


\section{Introduction}

\subsection{Landscape Resources}

All natural resources (energy and material: exhaustible or renewable, biotic or abiotic) of a territory require application of human resources (and capital?) to be exploited for the common wealth; their strong interrelations are responsible for the formation of the anthropogenic landscapes.

Pre-, early and industrial (over)exploitation of resources does not remain firm but vary according to time and the needs of each society. Landscape, thus, accommodates a diversity of diachronic productive practices that may overlap historical periods, technological evolutions and social transformations.

It is fundamental, therefore, to approach landscape during its historical evolution process embracing all resources (classified in consistent groups of resources) that probably gave rise to a variety of human activities; all of them embody heritage values - "subjectively" or "objectively' perceived"- their assessment, though, is a matter of an on-going process of the civil society.

\subsection{Cultural Landscapes and Industrial Heritage}

For the purposes of the European Landscape Convention (ELC, Florence 20.10.00) "landscape" means an area, as perceived by people, whose character is the result of the action and interaction of natural and/or human factors. The genesis of the notion of cultural landscape is more likely laid on the multilayered dynamic interrelations -both spatially and historically- of human intervention and natural processes in order to adjust its function and spatial structure better to the changing community demands. Its theory provides a way to bring the tangible and the intangible qualities of a shared environment into focus, to highlight possibilities for understanding both history and identity, and to develop management plans (Antrop 2006).

The three main categories of cultural landscapes that are proposed by the World Heritage Committee -(a) Designed landscapes, (b) Evolved landscapes (or vernacular) b1) relic (or fossil) landscape, b2) a continuing landscape and (c) Associative landscapes (http://whc.unesco.org/en/guidelines/)- have difficulties to apply to less characteristic common industrial landscapes and so sub-categories are indispensable. In any case, industrial landscapes possess significant cultural, socio-economic, historical, natural, archaeological, scientific or technological value, at a local, regional, national or international level.

It is expected that industrial heritage actually tells the story of the emerging capitalism highlighting the dynamic social relationship between the "workers" and the owners of the "means of production". In current times of economic crisis, it may even involve a painful past with lost social, civil, gender and/or class struggles, a depressing present with abandoned, fragmented, degraded landscapes and ravaged factories, and a hopeless future for the former workers of the (not only) local society; or just a conquerable ground for new controversial investments. This is certainly an emotionally charged topic, with multiple readings and interpretations.

In effect, cultural industrial heritage deals with the "group of resources inherited from the past which people identify, independently of ownership, as a reflection and expression of their constantly evolving values, beliefs, knowledge and traditions" and "which they wish, within the framework of public action, to sustain and transmit to future generations" Council of Europe's Framework Convention on the Value of Cultural Heritage for Society (Faro Convention, 2005, Article 2-Definitions). Furthermore, it is anticipated to integrate the humanistic perspective of the study of "space" - people's spatial feelings and ideas in the stream of experience- and "place" - a unique entity with history and meaning that incarnates experiences and aspirations of people (Tuan, 1979).

At the beginning of the twenty first century, it is clearly acknowledged that, industrial heritage is understood, and interpreted at the level of the landscape and of societies. That broader interpretation of industrial heritage "focuses on the remains of industry - industrial sites, structures and infrastructure, machinery and equipment, housing, settlements, landscapes, products, processes, embedded knowledge and skills, documents and records, as well as the use and treatment of this heritage in the present". It should comprise "not only the remains of the Industrial Revolution, but also the traditional precursors from earlier centuries that reflect increased technical specialization, intensified productive capacity, and distribution and consumption beyond local markets, hallmarks of the rise of industrialization. Industrial heritage also includes the planning, policy-making and rehabilitation necessary to manage these remains in the face of deindustrialization" (Icomos/Ticcih Memorandum of Understanding, 2014). Therefore, the anthropological perspective more likely "values the attempt to understand the full range of values and valuing processes attached to heritage" (Getty 2012: 7), enlarging thus the common normative, techno-monument-centered approach or an (art) historical view privileged by the conservation field.

Hence, the urgent need for a harmonic synthesis of all industrial heritage values -including landscapes values in all their tangible and intangible dimensions- is inescapably emerging. 


\subsection{Scale of place, scale of time}

Any landscape structure requires a comprehensive and appropriate identification in terms of content, scale and context. The thematic and spatial scale of a -reserve, stock or potential- resource existence and exploitation is crucial for its study. Consequently, any interpretation of a landscape zone is eventually constrained by the scale of place -in accordance to the ecological significance that also imposes further limitations. "The urgent questions that are emerging from the study of the human dimensions of global environmental change" challenge the development of a common understanding of issues related to scale (Gibson, 2000: 236). Urban analysts, geographers, social, economic and political scientists and lately philosophers of science have potential to develop a synthetic theory at various scales of research activity. However, such consistent practical definition of the concept of scale does not exist, even within disciplines.

The challenge of the industrial heritage approach requires that both the scale of place and the scale of time be included in its study. The scale of time is decisive in order to understand actual landscapes. Although the precise description of the launching and ending of any 'industrialization period' at issue is normally blurred (or symbolically established in literature), three convenient categories of cultural landscapes (Antrop 2005) -incorporating the time scale- should be qualitatively recognized:

(1) The traditional landscapes from the earlier centuries up to pre-18th century, which have still preserved tangible testimonies and intangible values.

(2) The revolution age landscapes of the emerging and expanding industrialization and cities, which comprise the first (18 ${ }^{\text {th }}$ century-mid 19th century) and the second (mid 19th century-mid 20th century) industrial revolution. It is characterized by irreversible and/or traumatizing cultural and societal breaks with the past. Such practices gradually contributed to the degradation of spatial and social structures and relationships, to the discontinuity of historical links and to a failure of the historical reading of the landscape (Zacharopoulou-b, 2014).

(3) The post-modern landscapes, post World War II up to the $21^{\text {st }}$ century, has been characterized not only by increasing globalization, urbanization and deindustrialization but also by rising public awareness about "The Limits to Growth" (Meadows, 2005).

In fact, the emergence of the industrial revolution should be dated dynamically for each country and it is an on-going process in the 20th century i.e. quantitatively approaching; Britain (1750/60), France (1780), Belgium (1790), Germany (1795), United States (1800), Russia (1850), Japan (1860), Brazil (1929), India (1947), China (1953) etc. (Albrecht 2012).

Therefore, each country needs to define and document its own sub-frames of the industrialization process, though in the general framework of the global periodization system.

\subsection{Industrial neo-imperialism}

By the threshold of the twenty first century, having progressively formed as a discipline and re-tooled (Industrial, 2012), industrial heritage could hardly avoid being involved in social and political conflicts. Quoting Neil Cossons (TICCIH Congress 2012) "Industrial imperialism ensures its position and protects its future not by the conquest of distant lands as by the securing of its sources of raw materials ... The modern world is as much under the control of the major industrial powers as it ever was during the colonial era"; if such a case can the industrial heritage sector remain apolitical?

In the context of a long-term crisis of global capitalism, controversial mining investments (oil, minerals, coal and gold mining etc.) are reverting to the so called "developed" world; they are mostly pressing its fringe "vulnerable" areas but some are also touching the core of the capitalist societies. Extraction projects of potential, stock and/or reserve- resources of raw materials that were not feasible in the past are now implemented with the support of "cutting-edge technology and the Best Available Techniques (BATs)", though not always adequately tested. Unavoidably, the continuing expansion of "commodity frontiers" is triggering conditions of social and environmental degradation and conflict (Conte, 2014). So far, it seems that challenges can rise to the occasion of forming (or not) alliances between the movements that contest (over)extraction or others that "frame innovative alternatives to growth-laden development formulas" or "the movements of degrowth" (Conte, 2014) -which, uncritically, accept the notion of poverty as a natural law and overcrowding as an objective concept (Markantonatou, 2012)- or what else?

In any case, the limits to growth are not defined without the historical, social and political power relationships context, but actually reflect these relationships in accordance to the technological and ecological changes. From the beginning of the industrial revolution until now, there was always an "excess" part of laborers around the world -regardless of the limits of the actual population growth- that remain always a readily available exploitable human resource, for the changing needs of capitalism; either living in misery and disease, "consuming" poisoned air and improper food or forming a "convenient" reserve army of unemployment (Markantonatou, 2012). The history of the labor movement has not been adequately studied by the industrial heritage sector since now.

"Labor heritage refers to the part played by working people in making our communities, building our labor movement and establishing a democratic and fair society" (Irving, 2002). That heritage was created by 
workers who resisted at their lives degradation by any means; through organization of the labor movement, their work, and their participation in community life. Labor heritage, thus, mainly reflects the lives of men and women, young people and adults, indigenous people and the immigrants etc. (Irving, 2002).

In the wake of deindustrialization, a mass of well educated young people -e.g. countries like Greece are dramatically suffering by "brain drain"- is gradually added to the uneducated reserve army of unemployment of the past centuries. No young people's resistance recorded. In any case, the (non)struggles are a hot issue for study. This is definitely a new demanding matter of concern for the industrial heritage sector.

\section{Methodological issues}

\subsection{Methodological concerns}

The comparative scale of resource exploitation has to be highlighted as the key factor for the assessment methodology in close relation to the specific frame of a landscape and a historical period. The main difference between traditional and new landscapes resides in their dynamics, both in speed, and scale, as well as the changing perceptions, values and behavior of their users (Antrop 2005). A crucial -still loosely structured- study parameter, the so-called landscape capacity (i.e. the ability of a landscape to accommodate an imposed burden in a reasonable timescale) should be seriously taken into consideration by the industrial heritage discipline.

Up today, three main perspectives should be acknowledged; the natural sciences (e.g. landscape ecology), the human sciences (e.g. historical geography and historical ecology) and the applied sciences (e.g. landscape architecture and design perspective that "try to remodel and shape landscapes for the future in an attempt to steer the spontaneous and rather chaotic changes that go on" (Antrop, 2006:41). Generally, the discipline of the protection of monuments, sites and landscapes is suggested as subcategory of the latter perspective combined with nature conservation.

An inclusive diachronic study should identify and classify all resources (group of resources) that supported human activities and generated heritage values. The strengthening of the assessment criteria about what landscape characteristic values (tangible and intangible) deserve to be preserved or ignored -and why- will greatly support the methodology process.

However, any effort to break down and describe the values attached to a particular heritage site immediately encounters conceptual and practical difficulties. Bearing in mind the already considered characteristic typologies of heritage values, the views of various experts, citizens, communities, governments, and other stakeholders can be voiced and compared more effectively (Getty 2012:17).

Table 1 Characteristic typologies of heritage values

\begin{tabular}{|c|c|c|c|}
\hline $\begin{array}{c}\text { English Heritage } \\
(1997)\end{array}$ & $\begin{array}{c}\text { Burra Charter } \\
(1999)\end{array}$ & \multicolumn{2}{|c|}{$\begin{array}{l}\text { Getty } \\
(2012)\end{array}$} \\
\hline & & Sociocultural Values & Economic Values \\
\hline Cultural & Aesthetic & Historic & Use (market) value \\
\hline $\begin{array}{l}\text { Educational/ } \\
\text { academic }\end{array}$ & Historic & $\begin{array}{l}\text { Cultural } \\
\text { /symbolic }\end{array}$ & $\begin{array}{l}\text { Nonuse } \\
\text { (nonmarket) values }\end{array}$ \\
\hline Economic & Scientific & Social & Existence \\
\hline Resource & \multirow{3}{*}{$\begin{array}{l}\text { Social (including } \\
\text { spiritual, political, } \\
\text { national, other } \\
\text { cultural) }\end{array}$} & Spiritual/religious & Option \\
\hline Recreational & & Aesthetic & Bequest \\
\hline Aesthetic & & \multicolumn{2}{|c|}{$\begin{array}{c}\text { (proposed provisional typology of heritage values } \\
\text { Getty 2012: 9-10) }\end{array}$} \\
\hline
\end{tabular}

Regarding Greece, its landscape embraces a diversity of diachronic productive practices that may extend beyond historical periods, technological evolutions and social transformations. There is a significant time lag between global periodization system of industrialization and the relevant Greek process. Therefore, the following classification is proposed:

- The historical period before 1830 (when the Modern Greek State was established) including the transitional period between1830-1880.

Then, the following study periods are defined (Deligianni et al, 2012):

- Periods of early industrialization (1880-1920) and embedded industrialization (1920-1950); main issues on economy, production and labor.

- Postwar period (1950-1980) of dynamic expansion.

- The period after the restoration of democracy (1980-2000) of ongoing deindustrialization. 


\subsection{The stakeholders: insiders and outsiders}

The identification of stakeholders is an essential issue in value assessment and furthermore in the entire decision making process. The questions addressed are about who participates in the assessment, whose values are counted and, eventually, who has power to shape conservation outcomes. It is well-known that insiders stakeholders (such as public officials, bureaucrats, policy makers, conservation professionals et al.) are participating in the decision-making process where values are identified, assessed, and ranked, while other legitimate stakeholders (outsiders) are not present; both the process and the outcome will be improved by widening the circle of stakeholders. However, "the notion of including outsiders in conservation planning is fundamentally a political issue, a matter of power and authority" (Getty 2012: 17).

The understanding of "the conceptual levels of decision making ranging from constitutional choice, through collective choice, to operational choices is a prerequisite for the perception of the structure, processes, and outcomes of complex polycentric governance systems in a federal system" (Gibson, 2000: 234). In that context, the relationship of these conceptual and spatial levels can be demonstrated in analytical levels of human choice (constitutional-choice level, collective-choice level, operational-choice level) and geographic domains (international, national, regional, and community, household) (Gibson, 2000, Table 2: 235).

A sustainable future for industrial heritage in cultural landscapes should seek to empower public and private players to protect and sustainably manage. Post-industrial societies, being transformed under the combined effects of the economic crisis, energy transition, demographic or migration factors and a reduction in resources, call for new development models driven by greater democracy, strengthened citizen participation and better governance based on more open, reactive and transparent institutions. All the above concerns are included in the Council of Europe Framework Convention on the Value of Cultural Heritage for Society CETS No.: 199 (Faro Convention, 2005) which is open for signature by the member States and for accession by the European Union and by the non-member States. Greece has not signed or ratified the Convention yet (http://conventions.coe.int/Treaty/Commun/ChercheSig.asp? NT=199\&CM=8\& $\mathrm{DF}=\& \mathrm{CL}=\mathrm{ENG}$, status as of: 20-04-2015).

Despite the inherent contradiction of the insiders and outsiders due to their different relation to the decision-making processes, their values and interests do not necessarily conflict. Stakeholders on both sides might very well find reciprocal beneficial solutions by the same course of conservation action (Getty 2012: 17). It is an issue of "living together", quality of life and the living environments where citizens wish to prosper (Faro Convention, 2005) or, ultimately, it is just a matter of democracy.

\subsection{Conceptual scheme of an integrated approach}

The theoretical basis upon which it is possible to interpret heritage as cultural asset and to assess its sustainability characteristics as well as the requirement of making these ideas functional are fundamental. The latter must be tested by reference to several case studies of heritage projects all over the world. First of all, the practical application of these approaches aims at identifying the landscape resources (group of resources) characteristics. Multicriteria analysis may assist by classifying the components of the cultural (landscape and industrial heritage), environmental (scale of exploitation) and economic evaluations of the project, analyzing the project's outcomes against the agreed (stakeholders participation) criteria for sustainability and, finally, arriving at an overall conclusion synthesizing all tangible and intangible values of the project. Although the process seems chaotic, it is noteworthy that not all the parameters coexist in a certain project and also that various "coefficients of gravity" might be applied according to stakeholders' active or passive- involvement. Citizens can be both players and targets for actions in favor of the industrial heritage. The way they consider this heritage and what they expect from it vary from one country to another depending on whether they live -in a small community or big city- and on their country's particular industrial history.

All perspectives should be impregnated by the humanistic approach; all human sciences are more and more contributing in the process; the labor movement still remains an underestimated area of research; finally, human resources are diachronically the main factors.

Any methodology (Fig 1) finally adopted should be flexible, adaptable, variable, useful, and transferable. As there are so many different kinds of values, and the interactions among them are so complex, a more effective way of treating this issue has to begin with a clear, effectively neutral, agreed-upon way of characterizing different types of heritage value - as seen by the wide variety of stakeholders in conservation efforts. A typology of heritage values (Table 1) would be an effective guide to characterization-evaluation and would move towards a sincere and in depth debate in which all parties' values can be expressed and discussed (Getty 2012:17).

In spite of sounding utopian, it is probably the only democratic way for societies of every geographic domain to deal with and co-shape their own lives. 


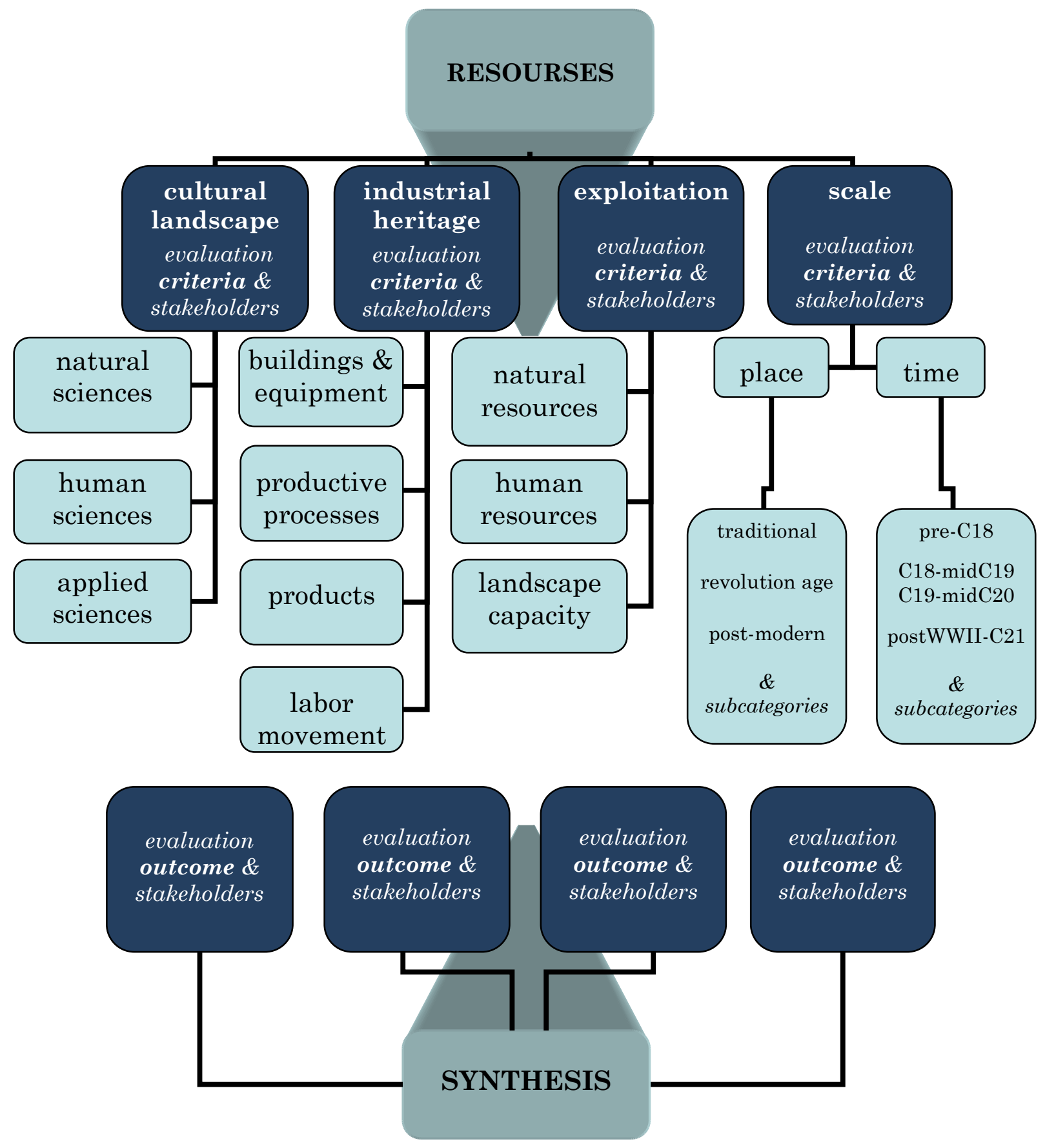

Diagr. 1 Conceptual model of an integrated approach

\subsection{Twenty first century challenges}

The Council of Europe's Framework Convention on the Value of Cultural Heritage for Society (the Faro Convention, 2005) is innovative in linking the concept of the 'common heritage of Europe' to human rights and the fundamental freedoms for which the Council of Europe is considered one of the historic guardians.

In current post modern context, it is evident that the industrial heritage approach requires an increasingly ecological standpoint where physical landscape should be seen within a larger cultural, social, economic and political landscape. However, the broader perceptions of the landscape and industrial heritage and also the growing influence of the environmental movement are expected to contradict to economic valuation process. 
It is more probable that the criterion of economy is commonly opposed to that of ecology mainly due to its inherent fundamental profit principles. In that conflicting context, "the political neutrality of the economic scientific dialogue on environmental issues is gradually questioned pointing to the low valuation of environmental resources in a free market economy, and the role of economists in legitimating this type of economic system" (Levallois, 2010, note7: 2).

Therefore, it seems that the major challenges of the twenty first century are:

a) The management of the industrial heritage in landscape contexts and within active, living territories, where cultural properties continue living with on-going -intensive (see paper's case study 1: a neoimperialistic investment) or mild (case study 3: the real estate pressure)- economic activities,

b) The suggestion of sustainable heritage practices (case study 2: tangible and intangible heritage values embodied in sustainable production process) and

c) The identification of new players in the field of industrial heritage (case study 4: resistance of workers' self-management).

\section{Greece's current state}

\subsection{The Greek legislative frame - highlights}

The first reference on "Landscapes of Outstanding Natural Beauty" is in 1950 (L.1469/1950 "On Protection of special category of buildings and works of art after 1830"). Important next steps are the revisions of the Greek Constitution in 1975 and in 2001 (Article 24) and, on parallel, the L.2742/1999 for "Land Use Planning and Sustainable Development". The concept of protection has been gradually following global trends and embracing both natural and anthropogenic landscape.

The L.3028/2002 "For the Protection of Antiquities and Cultural Heritage" (the so-called archaeological law) defines cultural values as the "evidence of the existence of individual and collective human activity" (Definition of terms, Article 2), and therefore incorporates the values of an industrial landscape. It also identifies that "the protection of the monuments, archaeological and historical sites should be included in the objectives of spatial, environmental and urban planning projects or any equivalent or/and substitutes of them" (Content of Protection, Article 3, §2).

\subsection{The implementation of the European Landscape Convention}

The European Landscape Convention (ELC, Florence 20.10.00) provided an updated strategic context towards the protection of a cultural heritage landscape -Greek L. 3827/10, FEK 30/A/25.02.10, "Ratification of the European Landscape Convention". In a European level, each country develops its own institutional tools for landscape design towards harmonizing the national level with the European Landscape Convention.

In that context, a synthesis of the typical types of Greek landscapes both identifying the local characterdefining parameters and based on geospatial data has been incorporated into the regional scale studies "Evaluation - Review \& Expertise of the adopted RSPFSD (Regional Spatial Planning Frameworks for Sustainable Development)" that are currently under consideration (total 13 regions). These studies provide strategic character directions at a national level. They are administered by the Ministry of Reconstruction of Production, Environment and Energy, whilst industrial heritage is under the jurisdiction of the Ministry of Culture, Education and Religious Affairs. It seems that there is no direct cooperation between the two Ministries for the implementation of the ELC. As of this moment, industrial landscapes have not been included in these studies as a particular type of landscape. However, they have a potential to be included in underlying design levels (Zacharopoulou-b, 2014).

As a representative case study, the RSPFSD of Central Macedonia - Step B.1 Special Landscape Section (http://www.ypeka.gr/Default.aspx?tabid=232, accessed 03-31-2015) is selected for presentation.

As a part of Northern Greece, Central Macedonia constitutes a Mediterranean geographic area where the long-settled common agricultural landscape has a rural character and encompasses hotspots of biological diversity, rich subsoil resources, mountainous, coastal and urban zones but also a multitude of archaeological findings as far back as the Neolithic period. Next section includes such evidence in order to further understand the region which is subdivided in seven regional unities; Thessaloniki, Halkidiki, Serres, Kilkis, Veria, Edessa, Katerini.

Each characteristic "place" is associated with multiple ideas and practices. This multiplicity creates the "layering" of Central Macedonia's landscape where eight characteristic zones of international, national, regional or local importance were identified (Table 2). The seven evaluation criteria (aesthetic and natural beauty, representativity, identifiability, unaffected character - remarkable quality, already recognized elements, uniqueness-rarity, and value as a natural resource) initiate an official national effort to accommodate modern global trends (http://www.ypeka.gr/Default.aspx?tabid=232\&language=el-GR) (in Greek). 
Table 2 Landscape zones' evaluation - RSPFSD Central Macedonia Region, GR Source: http://www.ypeka.gr/Default.aspx?tabid=232\&language=el-GR

\begin{tabular}{|c|c|c|c|c|c|c|c|c|}
\hline & \multicolumn{8}{|c|}{ LANDSCAPE ZONES of CENTRAL MACEDONIA, GR } \\
\hline $\begin{array}{l}\text { EVALUATION } \\
\text { CRITERIA }\end{array}$ & \begin{tabular}{|c|} 
Olympus \\
mountainous \\
landscape \& \\
surroundings
\end{tabular} & $\begin{array}{l}\text { Halkidiki's } \\
\text { landscapes }\end{array}$ & $\begin{array}{c}\text { Border } \\
\text { landscape }\end{array}$ & $\begin{array}{l}\text { The wine } \\
\text { roads }\end{array}$ & $\begin{array}{l}\text { Koroneia- } \\
\text { Volvi Lakes }\end{array}$ & $\begin{array}{l}\text { The wider } \\
\text { area of the } \\
\text { plain of } \\
\text { Thessaloniki }\end{array}$ & $\begin{array}{c}\text { Narrow and } \\
\text { River Valley } \\
\text { Aggitis - } \\
\text { Alistrati }\end{array}$ & $\begin{array}{l}\text { Proto, urban and } \\
\text { suburban } \\
\text { landscapes of } \\
\text { Macedonia }\end{array}$ \\
\hline $\begin{array}{l}\text { Aesthetic and } \\
\text { natural beauty }\end{array}$ & 0 & O & $\bullet$ & O & $\bullet$ & $\bullet$ & $\bullet$ & - \\
\hline Representativity & Q & 0 & $\bullet$ & $\bullet$ & • & $\bullet$ & $\bullet$ & • / \\
\hline Identifiability & 0 & 0 & O & o & $\bullet$ & • & o & ○ \\
\hline $\begin{array}{c}\text { Unaffected character } \\
\text { - Remarkable quality }\end{array}$ & O & O & $\bullet$ & $\bullet$ & ○ & O & $\bullet$ & ০/• \\
\hline $\begin{array}{c}\text { Already recognized } \\
\text { elements }\end{array}$ & $\bullet$ & 0 & $\bullet$ & $\bullet$ & O & O & O & O \\
\hline Uniqueness-Rarity & O & 0 & O & O & $\bullet$ & $\bullet$ & O & - / \\
\hline $\begin{array}{l}\text { Value as a natural } \\
\text { resource }\end{array}$ & 0 & $\bullet$ & 0 & - & O & O & O & -10 \\
\hline EVALUATION & \multicolumn{2}{|c|}{ INTERNATIONAL } & \multicolumn{3}{|c|}{ NATIONAL } & \multicolumn{2}{|c|}{ REGIONAL } & LOCAL \\
\hline
\end{tabular}

๑: High / Internationally Important / Very Interesting

-: Medium / Nationally Important / Interesting

$\circ$ : Low / Common /Confined or of special interest
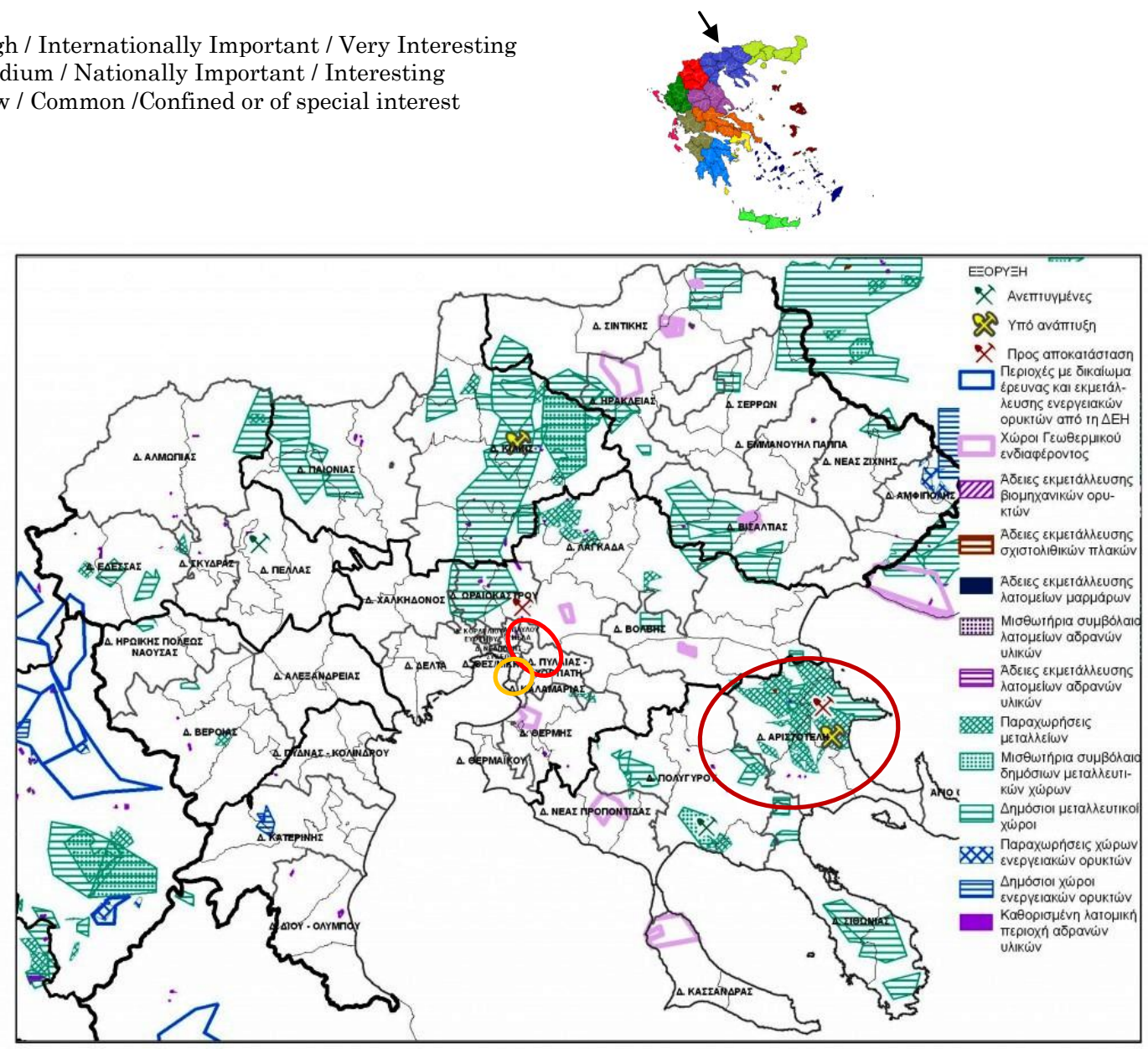

Fig. 1 The RSPFSD of Central Macedonia Region

Source: http://www.ypeka.gr/Default.aspx?tabid=232\&language=el-GR 


\subsection{Understanding the Central Macedonia Region, GR}

In Greece, economy and technology can be dated back to prehistoric times and to ancient Greek, Macedonian, Roman, Hellenistic and Byzantine civilizations. The roots of commodity production and accumulation are tracked in the Mediterranean countries in the sixteenth century. In the Greek territories of the Ottoman Empire, a widespread home-based craft production system was established in isolated (autonomous) villages, in commercial and maritime or shipbuilding centers in insular regions, as well as in rich olive, grape etc. cultivating regions. With the establishment of the Modern Greek State (1830), the economic activity gradually moved from the mountains to the plains and ports. The integration into the international economic system had accelerated since the mid nineteenth century, surpassing the stage of the industrial revolution.

In the pre-industrial period, the geomorphology of Central Macedonia determined the raw materials production chain and the relevant infrastructures, machinery and equipment. Hilly and mountainous areas and plains crossed by rivers (Aliakmon, Axios, Loudias, Strymonas, Aggitis) as well as extended coastlines characterize the region. Abundant sources of water in areas around the cities of Veria, Naoussa and Edessa favored installations which use the driving power of water; e.g. production of textiles (winding, spinning and knitting of wool, cotton and silk), grinding of cereals, extraction of olive oil and sesame oil, extraction of metallic and non-metallic minerals. Certain territories in the wider area of the plain of Thessaloniki and around the Koroneia-Volvi lakes, Veria, Giannitsa, Katerini (Olympus), and Halkidiki constituted the main granary of the region at that time. Extended tobacco production characterized the same areas and the plains of the rivers Axios and Strymon (Deligianni et al., 2012).

Commercial networks, within and outside the Ottoman Empire, facilitated the distribution of the manufactured products. The export trade was conducted mostly by caravans through the Balkan Peninsula or by commercial ships through maritime routes to Mediterranean ports, mainly Marseille and Livorno, as well as to other European destinations: Great Britain, the Netherlands, the Austro-hungarian Empire, the German and Scandinavian States, Poland and Russia. A large part of transportation was under Greek control, even in territories without Greek population. The interest of the European "Great Powers" to extend free market and to promote their industrial products was indicated by their efforts to control the land and water roots, constructing significant infrastructure works, and upgrading the railways. Concluding, up to 1880, the area was still dominated by a pre-capitalist economy. After 1880, great infrastructure projects promoted development which had an enormous strategic and economic impact. In 1888, the railway lines allowed the connection of Thessaloniki and Constantinople with the European network. In 1904, the construction of the modern Port of Thessaloniki was completed.

Northern Greece remained under the Ottoman rule until 1912. Its incorporation to the Greek State resulted as a consequence of the Balkan Wars (1912-13). During World War I (1914-18), Greece jointed the Triple Entente alliance (Great Britain, France, and Russia), in 1917. After Greece's defeat in 1922, a massive exchange of population between Greece and Turkey occurred, having an important impact on the development of agriculture; the multi-cultivation system was introduced and new methods and products were experimented. Further, major infrastructure projects, implemented on the plain of Thessaloniki in the late 1920s (including vast land reclamation works), contributed actively to the boosting of the region's economy. During the aforementioned period of constant wars, a new wave of industrialization, which was not accompanied by transformation and modernization of the production structures, emerged, while the strong presence of traditional agricultural activities, such as small family farms and trade of agricultural products was still apparent.

The World War II -followed by the occupation of the country (1941-44) by the Germans, Italians and Bulgarians- and the following civil war (1945-49), destroyed completely the Greece's productive structure. The postwar reconstruction and development period particularly in Central Macedonia, can, in terms of capital restructuring and accumulation, be subdivided into three sub-periods: a) the period between 194853 , during which the high accumulation rates are due mainly to foreign plans for the economic recovery, b) the period between 1953-59 when the accumulation rates were stabilized at lower levels, and c) the period 1960-80, a period of intensive accumulation and expansion of the capitalist production.

During the period 1967-1974, a regime of dictatorship was imposed on the country by army officers. After the restoration of democracy the country had to face serious financial problems following the global energy crisis of 1973. During the two last decades of the twentieth century, the accession of the country to the European Union (1980), the removal of state protectionism and the increased competitiveness -leading to a high penetration of imported goods in the country- contributed to growth.

Summarizing, for the first century of industrialization (1880-1980), the Greek model of industrial development, with emphasis on Central Macedonia, demonstrated the following main characteristics a) The main sectors of industrial expansion were those in relevance with intermediate, labor-intensive and consumer goods and energy, b) Paid labor was incorporated into production through paternalistic management policies without applied principles of scientific study and organization, c) Family businesses were promoted in many different ways. The drift of agricultural classes towards Greek urban centers and abroad was combined with the promotion of self-employment (Deligianni et al., 2012). 
This development model does not constitute an underdeveloped "deviation" but a long-term growth strategy, with challenging dynamic parameters and significant delay factors. The Greek model "mixes" small and medium sized enterprises, craft industries, shops, informal activities, even large industries, with central and regional roads and residential areas (Deligianni et al., 2012). Despite the region's rich subsoil, large scale mining activities -similar to the European ones- never took place.

Since 1985, the industry of the study area appears to be entering in a difficult adjustment process in the frame of an unstable political and economic environment, dominated by global markets and increased competition. Significant changes have taken place; extensive privatization, diffused urbanization as well as growing atypical forms of work due to a massive inflow of the migrants' in the 90s. In 2002, Greece entered the Eurozone and euro was introduced as currency replacing drachma. After 2009 -in an era of global recession- Greece's debt crisis led to a humanitarian crisis. Urgent alternative strategies are needed, e.g. to (re)introduce sustainable production methods and products, renewable energy production, technological innovation etc.

Attempts to safeguard the Greek industrial heritage have been emerged since the early 90s. In Central Macedonia, three relevant ministries (Ministry of Culture, Education and Religious Affairs; Ministry of Reconstruction of Production, Environment and Energy; and Ministry of Macedonia \& Thrace) are responsible for the protection of monuments, listed buildings and ensembles, archaeological -historical sites and landscapes. In 2002, L. 3028/2002 "For the Protection of Antiquities and Cultural Heritage" introduced new provisions for the protection of cultural (included industrial) heritage. Besides, the creation and operation of the Technical Museum of Thessaloniki/Science Center and Technology Museum "NOESIS", the Water Supply Museum, the Railway Museum, the Open Air Water Museum of Edessa etc. -as well as special courses in every educational level- have contributed to the rising social awareness about the protection of industrial heritage.

\subsection{A synthesis suspended step}

It is easily derived from the above that the Greek cultural landscape and its industrial heritage have been subjected to partial ineffective protection policies. Planning with objectives and future orientation and also a design process with a vision, free of bureaucratic processes, are urgently needed. The close collaboration between the responsible Ministries is indispensable for the integrated approach towards the protection of landscapes and their tangible and intangible embedded values. In any case, "a new holistic synthesis necessitates more elaborated transdisciplinary cooperation" (Antrop, 2006:41). The industrial heritage sector should constitute an exceptional link of this collaboration chain.

The Greek dept crisis encouraged suggestions (and/or implementations) of incompatible productive use and investment planning that imply irreversible and irreparable effects on the environment, society and economy and are only faced through social information and awareness. The stakeholders are supposed to "promote an integrated approach to policies concerning cultural, biological, geological and landscape diversity to achieve a balance between these elements" and to "reinforce social cohesion by fostering a sense of shared responsibility towards the places in which people live" (Faro 2005, Article 8, b, c).

Current case studies of passive and/or active involvement of local communities, in synthesizing and enhancing landscape's "spirit" -the humanistic perspective-, its diachronic industrial heritage and the embedded tangible and intangible values will support a pragmatic -not a suspended- step towards a sustainable future. Yet, the question persists: Will "aggressive" investments benefit Greece? So far, the evidence suggests it will not. Four characteristic regional case studies are presented as the most challenging alarms for the twenty first century.

\section{Central Macedonia's Region challenging case studies}

\subsection{A neo-imperialistic investment - Diachronic gold mining in NE Halkidiki, GR}

As demonstrated, Halkidiki's area is a multi-layered cultural landscape. The zone evaluation (Table 2) concluded in: 5 criteria of high/internationally important/very interesting; 1 criterion of medium/nationally important/interesting; and 1 criterion of low/common/confined or of special interest. These layers become separate cultural landscapes, overlapping but with independent boundaries and characteristics.

At present, three of them have to resolve severe conflicting values; one layer is associated with the intangible significance of the sea coastline and its tangible branches; another is centered on the mining and industrial complexes of the mountainous volume -both layers of high aesthetic, ecological and natural beauty; and a third intangible layer is related to the community cohesion. That is due to political choices and economic interests that have been trying to promote an economic mining monoculture for many decades, despite the fact that the mining activity is competitive to other sustainable local economic activities such as tourism, agriculture, livestock, fishery, beekeeping, and forestry. All the above mentioned layers are irretrievably influenced by Eldorado's neo-imperialistic investments to crisis-laden Greece. 
In the fringe of Europe, Eldorado has operations in Turkey, Romania and Greece. It is running two operating mines in Turkey: Kisladag and Efemcukuru. Combined, these three produced over 410,000 ounces of gold in 2014. In Romania, Eldorado is advancing the Certej project. In Greece, it operates one mine in NE Halkidiki: Stratoni, a small silver-lead-zinc deposit. Eldorado has also three "development" projects in NE Halkidiki: Olympias which is being "re-developed" in phases producing gold from the Olympias tailings rehabilitation project, Skouries which is a high-grade gold-copper porphyry deposit. Finally, the planning expands to Perama Hill (Thrace region), an epithermal gold-silver deposit and further on potential deposits to Serres and Kilkis areas. The NE Halkidiki's gold reserves and resources -which are estimated about 435 million tons, as of December 31, 2014 (http://www.eldoradogold.com/assets/resources-and-reserves/)- will be extracted the next 27 years. To provide scale context, less than 33 million tons were extracted from prehistoric times till today (https://soshalkidiki.wordpress.com/category/in-english/). The comparative scale -both of time and place- of exploitation is particularly alarming.

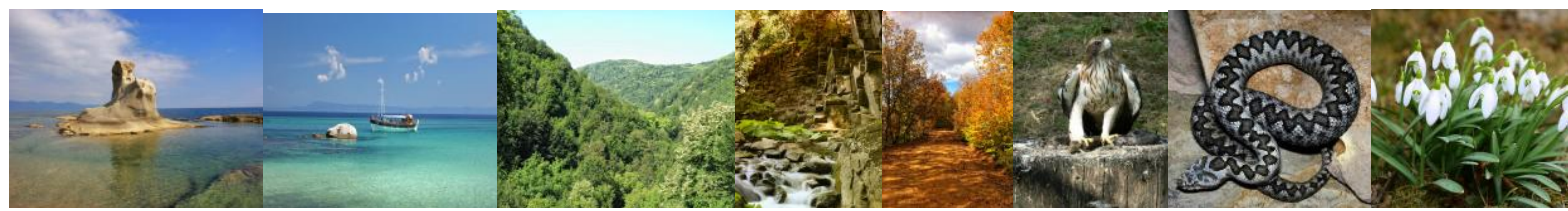

Fig. 2 Halkidiki's diverse, biologically important, natural landscape Source: www.soshalkidiki.wordpress.com, accessed 18-03-15

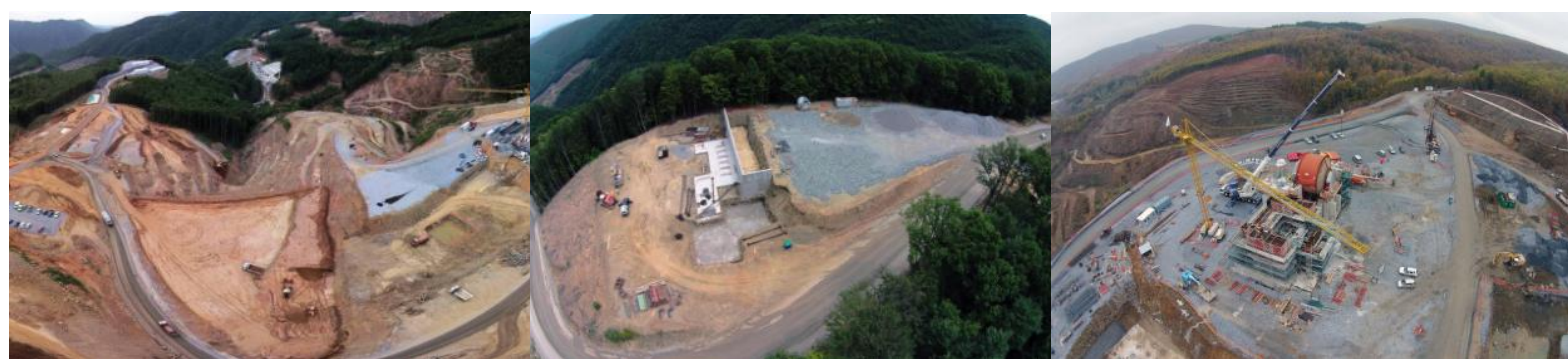

Fig. 3 Halkidiki's Skouries on-going activities up to November 2014

Source: http://www.eldoradogold.com/assets/europe/projects/skouries, accessed 26-05-15 (fig. left \& mid) http://www.hellas-gold.com/metalleia/metalleio-xrysou-skouries, accessed 27-05-15 (fig. right)

Historical literature and recent research indicate that Northern Greece is probably the richest gold-bearing region in Greece and even in SE Europe. The oldest objects of gold were found in settlements in Central and Eastern Macedonia, in the sixth millennium BC. Mining activities in Halkidiki -Cassandra Mines-were present since early classical antiquity (Vavelidis, 2013). Recent research in the area of Kipouristra (west of Olympias in NE Halkidiki) on ruins of metallurgical furnaces and piles of metallurgical slags show that metallurgical activities took place mostly during the late Byzantine and post-Byzantine period (1431-1656 AD) (Vavelidis, 2012). However, the presence of residues of metallurgical slags demonstrating different processing characteristics is also a strong evidence for earlier phases of metallurgical activity. Historical sources also prove systematic exploitation of the NE Halkidiki deposits from the fifteenth to the seventeenth century $\mathrm{AD}$. In 1705, the villages of the NE Halkidiki acquired the royalty to exploit the silver mines and were renamed to "Mantemochoria". From 1893 to 1908, the Ottoman Company "Cassandra Mines" gradually extracted other resources as well. It was in 1927 when the "Hellenic Company of Chemicals \& Fertilizers LtD" had fully been activated in the region (Vavelidis, 2012). After the WWII, "Cassandra Mines" (acquired then by the Greek capitalist Bodossakis Athanasiadis) continued operating up to the 70s. In 1992, the company went through special liquidation process by the National Bank of Greece. The "Cassandra Mines" (mining royalties and infrastructure of three mines: the Madem Lakkos Mine, the Mavres Petres Mine and the Olympias Mine) were "transferred" to TVX Hellas S.A., a subsidiary of the Canadian multinational mining company TVX Gold, in 1995. From that point on, the scale of exploitation served the investment orientations of a multinational mining company and, as a result, social conflicts emerged.

Unfortunately, that aforementioned long mining and industrial heritage was not approached, studied or protected systematically. Yet, questions need to be addressed, either concerning the elimination of waste products (depollution) and/or the interpretation of waste products (e.g. slag heaps) as it still bears witness to an industrial process. This criteria approach will allow for an analysis and comparison of programs of economic and industrial development that can sometimes affect the heritage adversely. Finally, a symbolic fact as to how useful the know-how could be is noteworthy; after the destructive earthquake of 1978 (epicenter Volvi lake) miners' know-how and experience (intangible value) in bracing mining galleries proved invaluable, as they promptly and efficiently implemented emergency retaining measures in damaged world heritage monuments' -mainly byzantine churches- in Thessaloniki. 
In 2002, after local community active involvement, the Council of State - Greece's Supreme Court on administrative matters- decided that the potential risks of the investment are greater than any economic and social benefits. In 2003, TXV Hellas S.A. stopped its operations in Halkidiki and soon afterwards all the assets of the "Cassandra Mines" were transferred to a purposely created company Hellas Gold S.A. in a "private transaction intermediated" (!) by the Greek State (Eldorado's opinion). Since then, "dubious political machinations between Greek Government officials and private companies, scandalous agreements against the interests of the Greek State, and a violent police crackdown on locals who protest against the mines, also hang over this deeply divisive issue" (http://antigoldgr.org/). In 2004, European Goldfields Ltd acquired "Skouries" and, in 2007, the 95\% of Hellas Gold S.A. In 2012, Eldorado acquires full possession of the minerals contained in the NE Halkidiki via the acquisition of European Goldfields Ltd. The controversy over gold mining in Halkidiki -a place of natural beauty of international importance- and the grassroots movement (http://www.collinsdictionary.com/dictionary/english/) against such an investment radicalized because of the fact that mining and metallurgy are forms of heavy industry fraught with dangers e.g. serious and irreversible damage to the natural environment, biodiversity, air pollution, water resources, the soil etc. as well as effects on human health and life quality. Claims such as "... even if the environment suffers to a point that's a fair price to pay for such an investment, which will bring much needed development to crisis-laden Greece" (http://antigoldgr.org/) are scientifically unsound. The Environment Board of the Aristotle University of Thessaloniki investigated and found the expansion "will radically change the character of the wider region, which has a rich and unique natural habitat, an important historical and cultural landscape, with archaeological sites and a large room for development of the agricultural and tourism sectors" (https://soshalkidiki.wordpress.com). Certainly, current generation is not legalized to plunder landscape resources created in millions of years and, consequently, to jeopardize the -reserve, stock or potential- resources and quality of lives of next generations.

It is true that "the industrial archaeology of the future is, after all, being created in the here and now" (Orange, 2014); also that understanding and preserving the industrial heritage requires the sharing of values, skills, memory narratives and oral history that can serve as a tool for relations between the generations. As a final point, an open -full of messages- letter from local women who are fighting against the expansion of the mining activities and gold mining is quoted: "We are the great-grandmothers who experienced the occupation during WWII and decided - never again fascism. We are the grandmothers who experienced civil war and declared -never again war. We are the mothers who saw our children becoming immigrants and declared -never again racism. We are the daughters who experienced the dictatorship and declared -never again authoritarian regimes. We are the granddaughters who have never before experienced occupation, civil war, immigration or dictatorship and are now experiencing all of them simultaneously. We are the great-granddaughters who dream, who hope, who demand a better future ..." (https://soshalkidiki. wordpress.com/category/in-english/).

Halkidiki's case is not unique. For the past 18 years another Canadian-Romanian mining company has been pursuing permission for a large new open-cast mining project at Rosia Montana, a well-known gold and silver mining site -rich in tangible mining heritage since Roman Times- in the western range of Romania's Carpathians. After many years of campaigning, ICOMOS and Europa Nostra not just demand rescue action and development planning based on a sustainable use of cultural and natural heritage assets, but they commit to get actively involved into such processes. Despite the on-going political and administrative engagement with the mining project, what can be urgently done are independent actions, extensive research and conservation at those parts of the site owned by the local community to prevent destruction. That does not seem to be understood among the public administration yet (Bâlici, 2013, Bâlici-Iamandescu, 2015).

Greece has considerably delayed in acting towards this direction.

\subsection{Tangible and intangible heritage - The 'decline' of lime putty production, GR}

Lime production has a long lasting history in Greece dated back to prehistoric years. For centuries, lime was the dominant binder in structures usually combined by local pozzolans. Typically, historic masonry structures were constructed from locally resourced and manufactured structural units (stones and bricks), aggregates and air binders (mainly limes) or slightly hydraulic (early cements). Up to the early twentieth century, basic demands were locally satisfied. The most important lime production and consumption area in Northern Greece was Thessaloniki because of the higher demand on housing construction. However, local producers of building materials were spread in every city (Florina, Kozani, Veria, Serres, Halkidiki, Drama etc). Before 1912, cement and steel products for structural reasons were imported in Central Macedonia (still a part of the Ottoman Empire) mainly from Europe. For almost 60 years, then, masonry bearing systems (lime intensive) and concrete construction models (cement intensive) -and all the transitional structural types in between- coexisted in Greece; the former mainly in rural areas and the latter in major economically developed cities. The ratification of the first Greek "Code of reinforced concrete" (1954) and soon afterwards the first "Antiseismic code" (1959) became the key point for the domination of the concrete 
structural model in Greece and led to the fast development, not only of the domestic production of modern cement and structural steel forms but also to significant investments in the Balkans and internationally.

The author's study on the live local lime production and know-how started in '90s and it is still going on. The first research stage was concluded in an inventory of lime kilns with historical and technological significance dating to the late seventeenth century and found in Asvestochori, a lime village in the vicinity of Thessaloniki, Greece. Verbal and written sources as well as in situ survey identified two areas of development and activity closely related to two nearby quarries. The need to preserve historical patrimony was emphasized; research included both tangible (industrial landscape, constructions, machinery and equipment) and intangible dimensions (deep understanding on the existing know-how, lab research and documentation of "good" lime putty production, market study, sustainable combined conservation strategies). Furthermore, the author investigated emerging issues related to the influence of the future deactivation of the quarrying area (including the kilns); alternatives to the environmental restoration of the industrial landscape were also discussed. Such a holistic approach has the potential to innovatively protect the industrial heritage site, i.e. support and promote passive (creation of a cultural space inspired by open-air museums), as well as active actions ("sustainable lime heritage", analytically Zacharopoulou, 2011).

Till now, the stakeholders -insiders and outsiders- were not activated effectively (with the exception of a slight strategic reference in the RSPFSD of Central Macedonia). In addition, the consistent diachronic tradition and know-how in lime putty production was not adequately supported, so gradually declined. It seems that the formation of a newly lime branch association (http://ime-association.gr/) (16 members) has the potential to develop innovative strategies, so as to become competitive in construction, on the grounds of sustainable development (small scale production, authenticity and distinctiveness, product differentiation, product quality, product safety, research innovation etc). So far, the association's objectives are different.
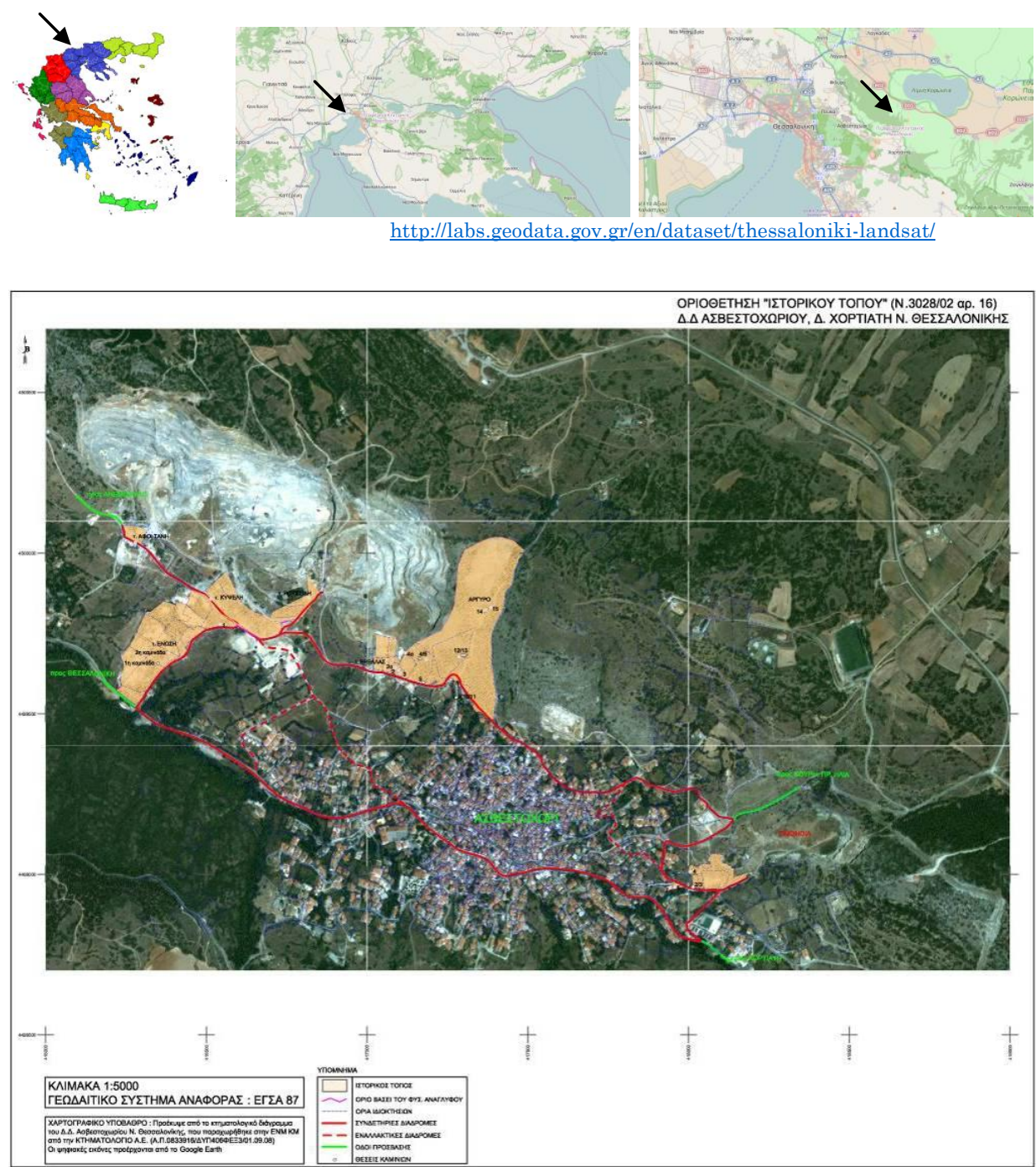

Fig. 4 The industrial landscape of Asvestochori (Lime village) - "Historic site" of lime production 


\subsection{The real estate pressures - Demolition of the VI.AMYL. industrial complex, Thessaloniki}

VIA.MYL., a corn sweeteners materials plant, was first founded and developed in Rendi, Athens, in 1926. The founder of VI.AMYL., Mr Sp. Kouvertaris, was born in Piraeus (1897) and studied chemical engineering at the University of Lausanne. After working for a while in his father's non profitable distilling factory, he went to Munich to further his education. He specialized in starch, inspired by a Greek entrepreneur from Alexandria, Egypt. After WWII -when everything was destroyed- a new VIA.MYL. factory was constructed, in Thessaloniki, in 1953. He was succeeded by his son in law Michael Kasimatis, in 1964 (http://www.tovima.gr/finance/article/?aid=127679).

In the 50s and the 60s, modifications in corn and sugar policies (corn was commonly a cheaper raw material than sugar) affected the branch directly. Gradually, the need to import technological innovations became pressing. In the early 70s, the industry transformed from "work intensive" to "capital intensive" through its cooperation with "Amylum" from Belgium. After Greece's accession to the European Union (1980), the company created high debts due to low level management. In 1988, it was sold to "Amylum" which then sold it to "Tate and Lyle" of British interests.

The unfavorable change for the Greek sugar production quota in E.E. encouraged "Tate \& Lyle" to demolish the industrial complex (2008) and move its operations in Razgrad plant, Bulgaria. Only some black flags in the entrance were the evidence of the workers' tepid reaction. Moreover, "Tate \& Lyle" was subsidized by 13 million Euros for a safe elimination of hazardous materials (http://oikomargarita.blogspot.gr/).

So far, dept crisis has been slowed down the potential real estate (in/compatible) "investments" in VIA.MYL.'s property by the seaside. Further interdisciplinary systematic study is needed for better documentation and interpretation of the lost industrial heritage and its impact in the community; or even a potential inspirational strategic design (Zacharopoulou a-b, 2014) of the seafront that would be also beneficial to the public.
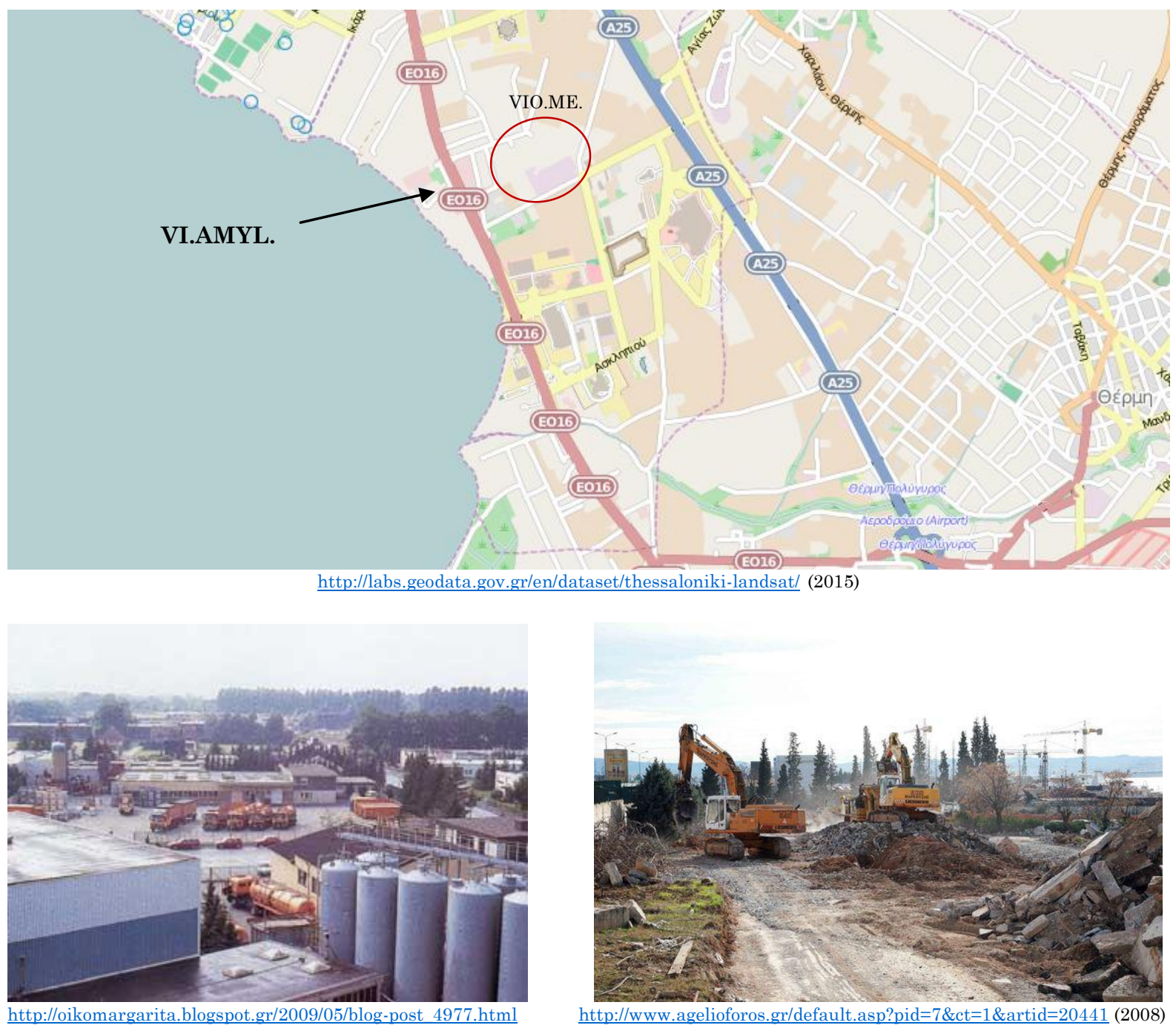

Fig. 5 The VI.AMYL. factory Thessaloniki, GR - location, buildings, demolition 

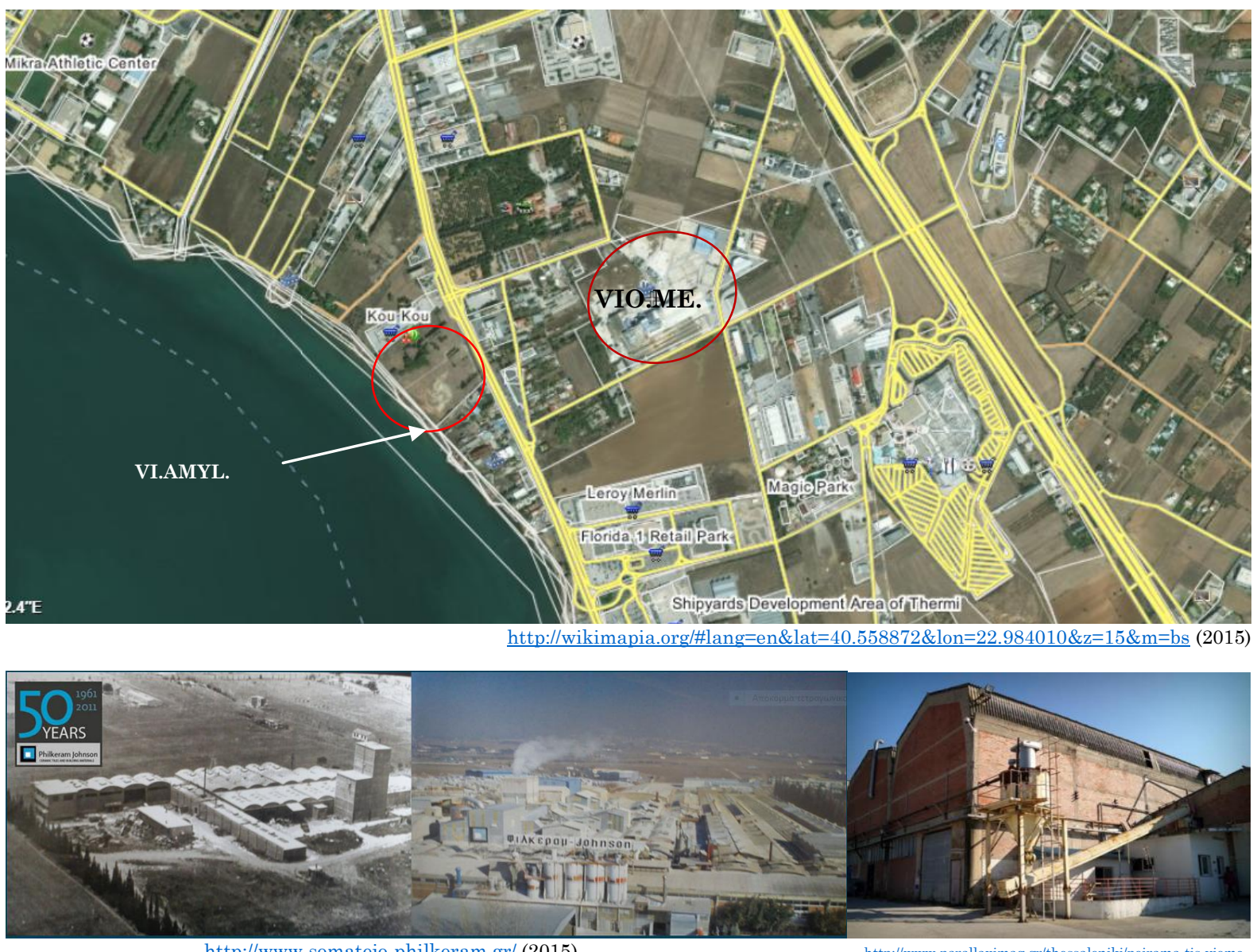

http://www.somateio-philkeram.gr/ (2015)

http://www.parallaximag.gr/thessaloniki/peirama-tis-viome

Fig. 6 The Philkeram-Johnson S.A. - VIO.ME. industrial complex, Thessaloniki, GR - location, buildings

Philkeram-Johnson S.A. was established by Philippou family in Pylaia-Thessaloniki, in 1961, i.e. in the beginning of a period of intensive accumulation and expansion of the capitalist production. Till 2008, Philkeram ceramics became a high profitable business and gradually expanded due to the excellent quality of raw materials, production process, research and development, technological evolution, quality control procedures etc. Industrial Mining (VIO.ME.), a subsidiary of Philkeram-Johnson S.A. was founded in 1982, and produced adhesives, joints, abrasive cleaners and related products. In the era of global crisis (between 2009-2010) Philkeram Johnson had the perfect pretext for declaring bankruptcy, in 2011 -dragging along VIO.ME. as well. However, it is said that the bankruptcy could have been avoided and that actually the firm was "abandoned" by its owners. As far this factory concerned, the liquidator announced auctions of machinery and spare-parts (http://www.somateio-philkeram.gr/, see also worker's complete archive).

The general assembly of VIO.ME.' workers decided to occupy and self-manage the factory branch under direct democratic workers' control on terms of equality and solidarity. Production started in early 2013, after a two years effort that has attracted attention and solidarity in Greece and worldwide. It was their own way to stand up against unemployment, poverty and depression. Since then, they have been producing and selling environment friendly cleaning products, ensuring a modest income for their families. The workers of VIO.ME. and the rising solidarity movement are now determined to resist to the clearance sale on-going process and to the liquidation of the machinery (incorporated to the buildings) and the spare-parts. The real estate interests are anxious to "invest", however, the workers declare "Our destiny is now in our own hands, we manage our work and our lives ourselves. We will not permit anyone to destroy what we have built with so much effort. We declare to the judges, the police, the administrators, the ex-owners and any prospective buyers: VIO.ME. is not for sale! VIO.ME. will remain in the hands of workers! ... It belongs to the workers and to society" (http://www.viome.org/).

The complex conflicting issues are still going on and -regardless of the outcome- the workers' selfmanagement initiative is highlighted here as an alternative way of managing the industrial heritage in the twenty first century. Further interdisciplinary systematic study is also indispensable. 


\section{Conclusion}

A few years into the twenty first century, it is clearly acknowledged that industrial heritage should be studied at the level of the landscape and of societies. Delimiting scale of place and time is decisive in order to understand and interpret past, present and future landscapes.

A diachronic study should embrace all landscape resources that probably gave rise to a variety of human activities and which embody heritage values. It is anticipated to incorporate the humanistic and environmental perspective of the study of landscape as a unique entity with history and meanings, which community wish, within the framework of public action, to sustain and transmit to future generations.

Taking into account that the inception of the industrial revolution should be dated dynamically, each country needs to define and document its own sub-frames of the industrialization process, though in the context of the global periodization system.

Greece's landscape accommodates a diversity of diachronic productive activities that may overlap historical periods, scientific invents, technological evolutions and social transformations. The conception of the industrial heritage's protection has been gradually following global trends and embracing both natural and anthropogenic Greek landscape. At the beginning of the twenty first century, industrial heritage could hardly avoid being involved in social and political conflicts as well as in the study of the labor or social movements.

In Greece, Halkidiki's cultural landscape -a landscape of exceptional multi-layered (sosiocultural and economic) value, internationally important- is at risk due to a large-scale short-term gold mining project which has a negative effect on all other activities in the area; as a result, social cohesion has broken. Other case studies also demonstrate conflicting values and complex issues about how the stakeholders might find mutual beneficial solutions for the public welfare that needed to be resolved. Lack of scientific support and technological innovation led a number of productive activities -such as long-lasting lime production- at a crucial crossroad; either to reclaim traditional successful knowledge and develop innovative sustainable know-how/products or to let multinational trends and companies to overlap them. Insufficient Greek management and unfavorable European quota regarding some agricultural products -e.g. sugar productionseem to have evidently resulted a turn down of Greek agricultural products' processing (corn, sugar, tobacco, cotton etc.) and a consequent devalue and/or demolition of the relevant industrial plants; some relocation of factories abroad have also occurred. The workers' self-management is pointed out as an alternative way of managing the industrial heritage in the twenty first century. In the wake of deindustrialization and the crisis, countries like Greece are dramatically suffering by "brain drain", since a high number of well educated young people leave the country.

In all cases, further interdisciplinary systematic study is indispensable; people can -and will- make the difference. Greece has considerably delayed in acting towards this direction.

\section{References}

ALBRECHT, Helmut: What does the Industrial Revolution Signify? in Industrial Heritage Re-tooled. The TICCIH guide to Industrial Heritage Conservation, ed. James Duet (2012) 7-23.

ANTROP, Mark: Why landscapes of the past are important for the future, in Landscape and Urban Planning, 70, (2005) 21-34.

BÂLICI, Stefan, IAMANDESCU Irina: The Rosia Montana mining landscape, Romania: an update and call to action, Report, TICCIH Bulletin, No. 67, 1st quarter (2015).

BÂLICI, Stefan: Rosia Montana: An overview on the question of cultural heritage, in Caiete ARA, 4, ARA Reports (2013) 205-228.

CONDE, Marta, WALTER, Mariana: Commodity Frontiers, in Degrowth: A vocabulary for a new era, ed. Giacomo D’ Alisa, Federico Demaria, Giorgos Kallis, Research \& Degrowth, and ICTA, Autonomous University of Barcelona, Spain Routledge, Business \& Economics, Nov 13 (2014) 248 pages.

COSSONS, Neil: Industrial Heritage: Treasure or Trash? in TICCIH Congress 2012, Series 2, Selected Papers of the XVth International Congress of the International Committee for the Conservation of the Industrial Heritage (2012) 11-22.

DELIGIANNI, Olga, GIALIS, Stelios, ZACHAROPOULOU, Georgia et al (greek research team et al): Industrial Evolution in the Black Sea Area - Examples from Greece, Romania and Armenia (IEBSA), Sub-Study 'Hellas - Study on the history of industrial development in Northern Greece and especially in Central Macedonia', , PROJECT MIS 275, Catalogue of the itinerant exhibition (2013) p. 164 (DOI: 10.13140/ 2.1.1863.5842, greek study-short report, text pp. 119-134, photo gallery pp. 59-76), full text in dvd, p. 500 (greek text p. 150), publisher: NOESIS Thessaloniki Science Center and Technology Museum, ISBN: 978-960-7619-15-0. DOI: 10.13140/2.1.1863.5842. 
GETTY Conservation Institute: Assessing the Values of Cultural Heritage, Research Report, Edited by Marta de la Torre, The Getty Conservation Institute, Los Angeles (2011).

GIBSON, Clark, OSTROM, Elinor, AHN T.K.: The concept of scale and the human dimensions of global change: a survey', in Ecological Economics 32 (2000) 217-239.

IRVING, Terry, TAKSA, Lucy: History, Heritage, and the Labor Movement_introduction, in book Places, Protests and Memorabilia - the Labor Heritage Register of New South Wales, publisher Industrial Relations Research Centre, UNSW, 2002.

LEVALLOIS, Clément: Can de-growth be considered a policy option? A historical note on Nicholas Georgescu-Roegen and the Club of Rome, Ecological Economics (2010), doi: 10.1016/j.ecolecon.2010.06.020.

LOURES, Luís, BURLEY, Jon: Post-Industrial Land Transformation - An Approach to Sociocultural Aspects as Catalysts for Urban Redevelopment, Advances in Spatial Planning, Dr Jaroslav Burian (Ed.), ISBN: 978-953-51-0377-6, In Tech, DOI: 10.5772/36380 (2012). Available from: http://www.intechopen.com/ books/advances-in-spatial-planning/post-industrial-land-transformation-an-approachto-socio-cultural-aspects-as-catalysts-for-urban-red

MARKANTONATOU, Maria: The problematic of growth within two crisis: «natural limits», overcrowding and disciplining of labor, in Positions, issue 128, July - September 2014, http://www.theseis.com/index.php?option=com content\&task=view\&id=1270\&Itemid=29

MEADOWS, Donella, RANDERS, Jorgen, MEADOWS, Dennis: Limits to Growth: The 30-year update, Chelsea Green Publishing, White River Junction (2005) Vermont 802-295-6300.

ORANGE, Hilary: Changing Technology, Practice, and Values: What is the future of industrial archaeology? in Patrimonio, vol. 6 (2014) 64-69.

TUAN, Yi-Fu: Space and place. Humanistic perspective, in Philosophy in Geography, S. Gale and G. Olsson (eds.), (1979) 387-427.

VAVELIDIS, Michael MELFOS, Vassilis; Study of the ancient metallurgical works in Kipouristra, Olympiada (ancient Stageira), NE Halkidiki, in Scientific Yearbook, Department of Geology, Aristotle University of Thessaloniki, Honorary edition in memory of Prof. Emeritus K. Soldatou, special vol. 101, Thessaloniki (2012) 9-16.

VAVELIDIS, Michael: Northeastern Halkidiki, an important mining and metallurgican center in ancient times, The Archaeological Project in Macedonia and Thrace, (in Greek with English abstract), 23, (2009)2013, 399-406.

ZACHAROPOULOU, Georgia (a): Claiming the industrial landscapes for youth. The parks of the $21^{\text {st }}$ century, in Industrial heritage and youth, international meeting in the context of "Thessaloniki Youth European Cultural Capital 2014", Thessaloniki, (2014). DOI: 10.13140/2.1.4604.5765.

ZACHAROPOULOU, Georgia (b): The industrial landscape as a cultural value. Historic (dis)continuities and modern interdisciplinary approaches, in 10th International Congress of the Hellenic Geographical Society, in Thessaloniki, Greece, (2014). DOI: 10.13140/2.1.1065.6324.

ZACHAROPOULOU, Georgia: Sustainable Lime Heritage - Seeking out combined Conservation Strategies, in Industrial Heritage - Ecology and Economy, XIV International TICCIH Congress 2009 in Freiberg, Germany, Selected Papers, (2011) 372-378. DOI: 10.13140/2.1.5089.8881.

http://antigoldgr.org/

http://labs.geodata.gov.gr/en/dataset/thessaloniki-landsat/

http://oikomargarita.blogspot.gr/2009/05/blog-post_4977.html

http://wikimapia.org/\#lang=en\&lat=40.558872\&lon $=22.984010 \& \mathrm{z}=15 \& \mathrm{~m}=\mathrm{bs}$

http://www.agelioforos.gr/default.asp?pid=7\&ct=1\&artid=20441

http://www.eldoradogold.com/assets/europe/

http://www.hellas-gold.com/

http://www.parallaximag.gr/thessaloniki/peirama-tis-viome

http://www.somateio-philkeram.gr/

http://www.tovima.gr/finance/article/?aid=127679

http://www.viome.org/

http://www.ypeka.gr/Default.aspx?tabid=232

https://soshalkidiki.wordpress.com/category/in-english/

The Framework Convention on the Value of Cultural Heritage for Society (Faro Convention, 2005), (http://conventions.coe.int/Treaty/Commun/ChercheSig.asp?NT=199\&CM=8\&DF=\&CL=ENG. 